\title{
PERAN BUSINESS INTELLIGENCE DALAM SOLUSI BISNIS
}

\author{
Siswono \\ Information Systems Department, School of Information Systems, Binus University \\ Jl. K.H. Syahdan No. 9, Palmerah, Jakarta Barat 11480 \\ sisbinus@yahoo.com
}

\begin{abstract}
The purpose of this study is to give examine the use of Business Intelligence as a critical technology solutions in the decision making by management. Business Intelligence application is able to address the needs of organizations in improving problem analytical skills encountered in making decisions with the ability to collect, store, analyze and provide access to data, as well as dovarious activities such as statistical analysis, forecasting, and data mining.
\end{abstract}

Keywords: business intelligence, organization, statsistik analysis, forecasting, data mining

\begin{abstract}
ABSTRAK
Tujuan penulisan ini adalah memberikan pandangan mengenai pemanfaatan Business Intelligence sebagai solusi teknologi yang penting dalam pengambilan keputusan oleh pihak manajemen. Aplikasi Business Intelligence mampu menjawab kebutuhan organisasi dalam meningkatkan kemampuan analisis masalah yang dihadapi dalam pengambilan keputusan dengan kemampuan mengumpulkan, menyimpan, menganalisis dan menyediakan akses data, serta melakukan berbagai aktivitas seperti analisis statistik, peramalan, dan data mining.
\end{abstract}

Kata kunci: business intelligence, organisasi, analisis statsistik, peramalan, data mining 


\section{PENDAHULUAN}

Pada masa kini persaingan dalam berbagai jenis industri memperlihatkan iklim yang semakin ketat. Dengan bertumbuhnya persaingan menyebabkan perusahaan memikirkan berbagai macam cara untuk mengungguli perusahaan pesaing atau setidaknya tetap mampu bertahan dalam industri tersebut. Di sisi yang lain, teknologi informasi mengalami pertumbuhan yang sangat cepat dengan berbagai macam keunggulan yang ditawarkan telah mendorong perusahaan mulai memanfaatkannya untuk melakukan perbaikan terhadap strategi pengembangan usaha maupun proses bisnisnya dalam upaya untuk memenangkan persaingan bisnis.

Berbagai macam teknologi informasi dikembangkan untuk meningkatkan efektifitas manajerial guna meningkatkan kinerja bisnis maupun organisasi. Business Intelligence (selanjutnya disingkat menjadi BI) merupakan salah satu teknologi yang mampu menjawab kebutuhan organisasi untuk meningkatkan kemampuannya dalam menganalisis masalah-masalah yang dihadapinya serta dalam pengambilan keputusan. Teknologi BI merupakan pengembangan dari aplikasi Knowlegde Management (KM), dengan menambahkan proses data analytics, yaitu dengan memanfaatkan data yang ada untuk menghasilkan suatu informasi baru yang bermanfaat. Aplikasi BI memberikan informasi yang personal, yaitu dengan melakukan proses pengumpulan, pengaturan dan penyebaran informasi secara personal.

BI telah banyak digunakan oleh organisasi-organisasi dalam mengelola data dan informasi sampai dengan dukungan pengambilan keputusan. Secara ringkas, BI dapat diartikan sebagai pengetahuan yang didapatkan dari hasil analisis data yang diperoleh dari kegiatan suatu organisasi. Business Intelligence solution merupakan istilah yang umumnya digunakan untuk jenis aplikasi ataupun teknologi yang digunakan untuk membantu kegiatan BI, seperti mengumpulkan data, menyediakan akses, serta menganalisis data dan informasi mengenai kinerja perusahaan.

\section{METODE}

Dalam naskah ini, penulis menggunakan pendekatan studi literatur melalui penelusuran teori yang diperoleh dari beberapa sumber pustaka maupun sumber lainnya. Diharapkan melalui pemaparan ini dapat dimanfaatkan oleh pembaca untuk menambah wawasan pengetahuan yang berkaitan dengan Business Intelligence sebagai sebuah solusi bisnis.

\section{HASIL DAN PEMBAHASAN}

\section{Business Intelligence (BI)}

Thomsen (2003) menyatakan bahwa terminologi BI menggantikan decision support systems, executive information systems, dan management information systems. Dalam perkembangannya terus meningkatkan kemampuan yang semakin canggih dalam memenuhi kebutuhan komputasi dan analitis perusahaan. BI didefinisikan sebagai sebuah sistem yang menggabungkan antara pengumpulan data, penyimpanan data, dan knowledge management dengan alat analisis untuk menyajikan informasi internal yang kompleks untuk para perencana dan pengambil keputusan.

BI adalah teknologi baru untuk memahami masa lalu dan memprediksi masa depan. Teknologi yang dimaksudkan disini adalah teknologi yang mampu mengumpulkan, menyimpan, mengakses dan 
menganalisis data untuk membantu para pengambil keputusan menghasilkan keputusan yang lebih baik. Sebagai sebuah aplikasi, maka BI meliputi aktivitas decision support systems, query dan reporting, OLAP (OnLine Analytical Processing), analisis statistik, peramalan dan data mining.

BI merupakan sistem dan aplikasi yang berfungsi untuk mengubah data dalam suatu perusahaan atau organisasi (data operasional, data transaksional, atau data lainnya) ke dalam bentuk pengetahuan. Aplikasi ini melakukan analisis data di masa lampau, menganalisisnya dan kemudian menggunakan pengetahuan tersebut untuk mendukung keputusan dan perencanaan organisasi.

DJ. Power mendefinisikan BI sebagai sebuah konsep dan metode untuk meningkatkan kualitas pengambilan keputusan bisnis berdasarkan sistem yang berbasiskan data. BI seringkali dipersamakan sebagaimana briefing books, report and query tools, dan sistem informasi eksekutif. BI merupakan sistem pendukung pengambilan keputusan yang berbasiskan data.

Berbagai kelebihan dalam penerapan BI, yaitu untuk mengumpulkan, menyimpan, menganalisis dan menyediakan akses ke data guna membantu pengguna mengambil keputusan secara akurat dengan melakukan berbagai aktivitas diantaranya, sistem pendukung keputusan, query, reporting, online analytical processing (OLAP), analisis statistik, forecasting, dan data mining untuk analisis data.Gambar 1 di bawah ini memperlihatkan bahwa gagasan tentang BI telah berkembang selama empat puluh tahun terakhir dan masih akan terus berlanjut. Nampak sekali bahwa BI berfokus pada data mining dan knowledge discovery. Ini merupakan aspek penting dari BI.

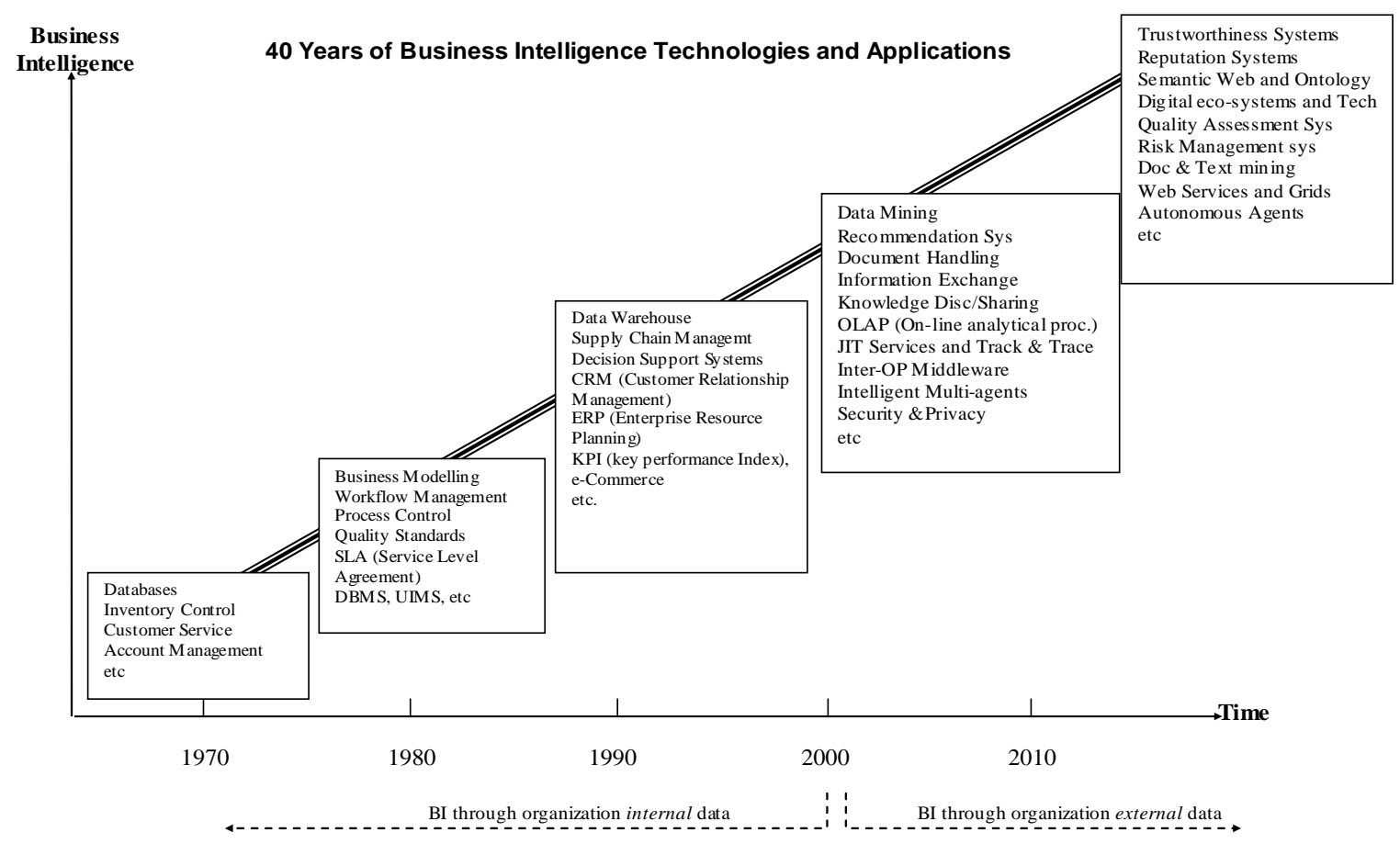

Gambar 1 Perkembangan Teknologi BI dan aplikasinya (Chang et al, 2006)

\section{Teknologi Business Intelligence}

BI menyediakan data dari organisasi sedemikian rupa sehingga pengetahuan organisasi dapat dengan mudah mengasosiasikannya terhadap data dan mengubahnya menjadi informasi bagi organisasi. Pengguna yang terlibat dalam proses BI dapat menggunakan aplikasi perangkat lunak dan 
teknologi lainnya untuk mengumpulkan, menyimpan, menganalisis, dan menyediakan akses ke data, dan menyajikan data dengan cara sederhana, yang berguna. Perangkat lunak ini membantu dalam manajemen kinerja Bisnis (Business performance management), dan bertujuan untuk membantu orang mengambil keputusan bisnis "lebih baik" dengan membuat informasi yang akurat, mutakhir (up-todate), dan ketersediaan informasi yang relevan yang ketika dibutuhkan. Beberapa perusahaan menggunakan data warehouse karena merupakan kumpulan informasi yang didapat dari berbagai database operasional untuk tujuan menghasilkan sebuah BI.

Berikut adalah beberapa alat yang dalam kategori BI, yaitu: business performance management dan performance measurement, business planning, business process re-engineering, customer relationship management (CRM), data mining dan data warehouse, decision support systems, executive information systems (EIS), human resources, knowledge management, management information systems (mIs), geographic information systems (GIS), online analytical processing (OLAP), supply chain management, web personalization and web mining, dan text mining.

\section{Keuntungan Aplikasi BI}

Ada beberapa keuntungan aplikasi BI yang dapat memberikan keuntungan bagi perusahaan (Schiff, 2010): (1) menghapus spekulasi (Elliminate Guesswork) - BI memberikan data histotoris yang lebih akurat, real-time update, sintesis antara menyimpan data departemen, peramalan dan tren, dan bahkan prediksi "what-if analysis" mampu menghilangkan angka perkiraan; (2) mendapatkan jawaban yang cepat untuk pertanyaan bisnis. Wende Cover, direktur strategic marketing pada MicroStrategy mengungkapkan bahwa pengguna BI dapat dengan cepat memperoleh jawaban atas pertanyaanpertanyaan bisnis, tidak menghabiskan waktu berjam-jam untuk membaca bertumpuk-tumpuk laporan tercetak; (3) mendapatkan laporan utama bisnis kapan dan di manapun dibutuhkan; (4) mendapatkan pengetahuan yang mendalam tentang perilaku pelanggan (customer behavior). Dengan menggunakan aplikasi BI memungkinkan perusahaan untuk memperoleh kejelasan apa yang pelanggan beli (atau tidak). Mampu mengubah pengetahuan tersebut menjadi keuntungan tambahan bagi perusahaan untuk mempertahankan pelanggan berharga; (5) mengidentifikasi peluang cross-selling dan up-selling. Aplikasi BI memungkinkan perusahaan untuk memanfaatkan data pelanggan untuk membangun, memperbaiki dan memodifikasi model prediktif yang membantu penjual untuk meng-up-sell dan cross-sell produk pada kebutuhan yang tepat dari pelanggan; (6) mempelajari cara untuk merampingkan operasi - dengan wawasan terperinci mengenai kinerja bisnis, organisasi dapat dengan mudah melihat di mana mereka perlu membuat perubahan untuk merampingkan operasi bisnis; (7) meningkatkan efisiensi - banyak perusahaan membuang waktu untuk mencari data dari berbagai sumber data yang tersebar di departemen-departemen untuk dapat memahami apa yang sedang terjadi dalam bisnis mereka. Jikalau beruntung dapat menemukan informasi tersebut, mereka masih perlu mengkonversi, menggabungkan dan melaporkan. Dengan menggunakan aplikasi BI, semua informasi terpusat dan dapat dilihat melalui dashboard atau mengubahnya menjadi laporan, menghemat waktu dan menghilangkan inefisiensi; (8) mempelajari biaya manufaktur sesungguhnya. Aplikasi BI dapat memberikan pemahaman yang lebih luas kepada pengguna terhadap biaya produksi dan kemampuan untuk menyesuaikan produksi dengan cepat untuk memperoleh keuntungan yang lebih besar; (9) mengelola persediaan lebih baik. Aplikasi BI dapat membantu mengetahui berapa jumlah yang diorder pada waktu yang tepat sehingga pelanggan menerima produk mereka ketika mereka membutuhkannya dan perusahaan tidak menanggung biaya kelebihan persediaan stok; (10) melihat di mana posisi bisnis di masa lalu, saat ini dan yang akan datang. Aplikasi BI telah berhasil menjelaskan apa yang terjadi pada bisnis selama beberapa periode waktu tertentu, misalnya, berapa banyak unit yang terjual, di mana toko, di mana geografi, atau di mana segmen pelanggan. Isu-isu tersebut dipahami bahwa keunggulan kompetitif berasal dari menganalisis data tidak terstruktur untuk memahami bagaimana dan mengapa hal ini dapat terjadi. 


\section{PENUTUP}

Dalam pengambilan keputusan, Aplikasi BI memanfaatkan pengolahan data berkualitas yang bersumber pada Data warehouse. Data warehouse itu sendiri berfungsi untuk menyimpan data yang berasal dari database transaksional yang terpisah dari berbagai lokasi penyimpanan yang disatukan untuk proses analisis.

Informasi yang dihasilkan oleh BI memberikan banyak manfaat bagi pengguna dalam pengambilan keputusan telah menjadikan BI sebagai solusi bisnis saat ini.

\section{DAFTAR PUSTAKA}

Chang, E., Dillon, T.S., Hussain, F.K. (2006). Trust and Reputation for Service-Oriented Environments - Technologies for Building Business Intelligence and Consumer Confidence. New Jersey: John Wiley and Sons.

Ranjan, Jayanthi. (2009). Business intelligence: concepts, components, techniques and benefits. Journal of Theoretical and Applied Information Technology, 9 (1).

Schiff, Jennifer. (2010). Ten Benefits of Business Intelligence Software. Diakses 12 Februari 2013 dari http://www.enterpriseappstoday.com/business-intelligence/ten-benefits-of-businessintelligence-software-1.html.

Thomsen, E. (2003). BI’s Promised Land. Intelligent Enterprise, (6) 4, 21 - 25. 